\title{
University-business-government relations in the development of the institutional environment of Russian regions
}

\author{
N.Y. Vlasova $\bowtie$, E.A. Lyashenko \\ Ural State University of Economics, Ekaterinburg, Russia; vnj@usue.ru
}

\section{ABSTRACT}

Relevance. University-business-government relations drive regional innovation. Therefore, in order to stimulate innovation, a favourable institutional environment is necessary.

Research objective. The article proposes an original methodology to examine regional institutional environment based on the analysis of the interactions between the government, business and universities.

Methods and data. The study relies on the statistical data on 12 Russian regions for a 6-year period. The data are used to create three sets of indicators characterizing the institutional sectors 'Government,' 'Business' and 'Universities'. Regions are divided into clusters and ranked according to the state of their institutional environments by calculating subindices and the integral index. Other research methods include cluster analysis and correlation regression analysis.

Results. The regions were grouped according to their innovation performance: in lagging regions, the interactions between the government, business and universities are inefficient, which means that their regional institutional environment is not conducive to innovation. The opposite situation is observed in the group of leaders. We also found that interactions between the government, business and universities have a direct influence on GRP.

Conclusion. For each group of regions, areas for improvement and the corresponding measures were identified. Interventions may vary in terms of intensity and government participation.

\section{KEYWORDS}

regional institutional

environment, university-businessgovernment relations, innovation

\section{FOR CITATION}

Vlasova, N.Y., \& Lyashenko, E.A. (2021) University-businessgovernment relations in the development of the institutional environment of Russian regions. R-economy, 7(4), 214-224. doi: 10.15826/recon.2021.7.4.019

\section{Отношения университетов, органов власти и бизнеса как индикатор развития институциональной среды российских регионов}

\author{
Н.Ю. Власова $\bowtie$, Е.А. Ляшенко
}

Уральский государственный экономический университет, Екатеринбург, Россия; vпј@ияие.rи

\begin{abstract}
АННОТАЦИЯ
Актуальность. Взаимодействие институциональных секторов государства, бизнеса, науки и образования становится источником инновационного развития региона, поэтому важно развивать способствующую этому процессу институциональную среду.

Цель исследования. В статье на основе авторского методического подхода проводится анализ региональной институциональной среды, основанный на оценке интеракций органов власти, субъектов бизнеса, науки и образования. Методы и данные. Исследование основано на анализе региональных статистических данных двенадцати субъектов Российской Федерации за шесть лет. Показатели сгруппированы в три группы, характеризующие функционирование институциональных секторов «Государство», «Бизнес», «Наука». Регионы делятся на кластеры и ранжируются в соответствии с состоянием их институциональной среды путем расчета субиндексов и интегрального индекса. Другие методы исследования включают кластерный анализ и корреляционный регрессионный анализ.
\end{abstract}

\section{КЛЮЧЕВЫЕ СЛОВА} региональная институциональная среда, взаимодействие государства, бизнеса, науки и образования, индикаторы взаимодействия 
Результаты. Регионы были сгруппированы в соответствии с их инновационной эффективностью: в отстающих регионах взаимодействие между государством, бизнесом и университетами неэффективно, что означает, что их региональная институциональная среда не способствует инновациям. Противоположная ситуация наблюдается в группе лидеров. Мы также обнаружили, что взаимодействие между государством, бизнесом и университетами напрямую влияет на ВРП.

Вывод. Для каждой группы регионов были определены области, требующие улучшения, и соответствующие меры. Вмешательства могут различаться по интенсивности и участию правительства.

\section{ДЛЯ ЦИТИРОВАНИЯ}

Vlasova, N.Y., \& Lyashenko, E.A. (2021) University-businessgovernment relations in the development of the institutional environment of Russian regions. R-economy, 7(4), 214-224. doi: 10.15826/recon.2021.7.4.019

\section{Introduction}

Persistent regional disparities, the lack of adequate infrastructure and centres of economic growth, the prevalence of low-technology industries in regional economies are among the most significant challenges that Russia faces. In order to address these problems, it is necessary to increase the efficiency of collaborative relations between the government, business and universities. Stable and productive relationships between these actors will produce a strong synergistic effect exceeding the individual effect that each of them is capable of producing. Only permanent and well-coordinated interactions between the government, business and universities within the triple helix model can generate innovation synergy. It is, therefore, important to improve the institutional environment on the mesolevel - the level where local territories can act as sources of innovation and socio-economic development in general.

This study is aimed at evaluating the regional institutional environment by analyzing the interactions between the government, business, and universities. Our research findings can be used by policy makers to stimulate innovation in specific regions.

This aim has determined the following research tasks:

- to study the approaches to the analysis of institutional environment;

- to develop a methodology for the analysis of institutional environment;

- to test this methodology by using the data on Russian regions;

- to identify the key areas of development of the regional institutional environment in Russian regions.

The structure of the institutional environment is complex and multidimensional. Since there is a lack of regulations or reference points that could be used to measure its development, the most productive approach to describe the institutional environment and reveal its potential is to conduct a cross-regional comparison.

\section{Theoretical framework}

In Russia, regionally focused research on institutional environment started to evolve in the 1990s. A significant contribution to this area was made by G.B. Kleiner and R.M. Nureev (2006, 2009), S.V. Doroshenko and E.V. Popov (2002), who analyzed the problems of regional and local development by using the methods of institutional economics. The key goal of such interdisciplinary studies is to investigate the connection between the meso-economic system and institutional space (Markov et al., 2009).

In our view, the regional institutional environment encompasses a variety of political, legal, economic, and social conditions produced by formal and informal institutions and their interactions. These conditions, in their turn, shape the activities of various economic agents in a specific territory.

The theoretical foundations for the research on institutional environment were laid by Douglass North (1997), one of the fathers of new institutional economics. North was interested in the impact of institutional quality on economic performance.

Within the vast body of theoretical and empirical research, both Russian and international, institutional environment may be analyzed by looking at different periods, markets and industries, on the national or regional levels. There are also studies that review and systematize the existing methodologies.

There is sufficient evidence pointing to the fact that institutions have a significant effect on regional development. There is, however, a problem of how institutions should be measured regarding their 
space and time variability; there are also difficulties in establishing the right mix of formal and informal institutions (Rodríguez-Pose, 2013).

E.D. Weisman and M.V. Podshivalova (2017) systematized the existing methodologies of institutional environment analysis and concluded that for an accurate evaluation of such a complex phenomenon, a combination of methods is required and that one methodology, even if it is well tried and tested, is not enough.

S.G. Kirdina et al. (2011) conducted a quantitative evaluation of the institutional changes and their speed, in particular the changes in the density of the institutional environment, the degree of its homogeneity and hierarchy.

Numerous studies investigate the significance of the relationships between different actors within the institutional environment. S. Dawley et al. (2019) focus on the regional institutions' efforts to attract and embed lead firm investments within global production networks. They evaluate the functions and role of the coalitions of actors that form a system of relationships within the framework of the institutional approach. S. Dawley et al. (2019) emphasize that regional institutions need to develop adaptive coupling creation strategies that co-evolve with the reconfiguration of production networks and changes in national institutional and political environments.

A separate group of studies are based on the triple helix model. For instance, a recent study by N. Yoda and K. Kuwashima (2020) concentrates on the case of Japan to model university-industry-government relations and to demonstrate that the qualitative parameters and the scale of collaborations change in response to reforms in regulations. Zhuang et al. (2020) designed a regional collaborative innovation evaluation model based on the triple helix theory. They analyzed the invention patent data of 31 provincial regions in China for the last 5 years and found that the relationship between the interactions of regional actors and the region's innovation potential is not quite linear since certain provinces with weak regional innovation capabilities have a relatively close cooperation level and vice versa.

The closest to our understanding of the problem is the study by D.L. Napolskhikh (2014), who defines institutional environment as a network structure encompassing multiple interactions and mutual effects, falling within what he describes as the 'neural synapse model'. Napolskikh proposes to measure the efficiency of an institution by calculating the ratio of savings from cutting the transaction and operation costs to the losses caused by institutional restrictions. Density, cohesiveness, complementarity and conductivity of an institutional environment are the criteria that can be used to measure its efficiency and potential to foster innovation.

Analysis of the institutional environment can rely on macro-economic indicators and statistical data, expert surveys, surveys of the key stakeholders and so on. Some studies include calculations of the parameters of certain institutions (for example, the number of legal norms). These methodological approaches underpin the evaluations of institutional environment conducted by Russian and international organizations.

A separate group of studies is devoted to the institutional factors in the development of regional innovation systems. For example, Ott and Ronde consider the processes of knowledge transformation in the sphere of innovation inside the 'black box' of the regional innovation system (2018).

What all these methodologies have in common is their interdisciplinary nature, in other words, they use not only economic but also non-economic indicators, characterizing the legal, political and social processes in individual communities, countries, regions, industrial sectors, and in the world.

It should be noted, however, that only few studies provide a comprehensive analysis of the institutional environment on the national and regional levels. Moreover, there is no commonly accepted methodology to evaluate all the parameters of such an environment. What is worse, many such studies lack robust conceptual foundations and there is still a perceived lack of working concepts that such analysis can be based on.

In this study we rely on the eco-systemic approach to innovation and economic development: the innovation system is seen as a dynamic complex of economic agents and their multi-dimensional internal connections, it also includes a special environment formed through ideas, technologies, rules of the game, social interactions and culture (Mercan, Göktaş 2011; Bramwell, 2012). In their collaborative relationships, the government, business and universities begin to perform untypical functions and thus generate an institutional environment conducive to innovation. Some studies focus on particular groups of actors, showing their role in the formation of the institu- 
tional environment and innovation. M.C.J. Caniels and $\mathrm{H}$. van den Bosch mainly focus on the role of higher education institutions as drivers of innovation. L. Fonseca and L. Nieth (2021) emphasize that in order to enhance the role of universities in regional innovation, strategic coordination is necessary, both within the universities and with regional bodies (2011).

Robust coordination of efforts between the government, universities, and businesses is crucial for the creation of triple-helix synergy in innovation systems (Leydesdorff, 2008; Smorodinskaya, 2011) and high technology milieux for spatial transfer of knowledge (Capello, 1999). Quite illustrative in this respect are the cases of Sweden and Finland where regional innovation eco-systems were created through the networks of actors in a bottom-up manner (Smorodinskaya, 2015; Harmaakorpi, Rinkinen, 2020; Hasche et al, 2020).

\section{Method and Data}

Some methodologies (Weisman \& Podshivalova, 2017; Prokin, 2016) use official indicators characterizing the specific conditions and resources and their impact on innovation. In contrast to other available methodologies, we propose to concentrate exclusively on the indicators characterizing the interactions between different institutional sectors. We believe that the state of institutional environment is mostly shaped by the development of interactions between the institutions.

The proposed approach gives due regard to the impact of interactions between government agencies, businesses, and universities on regional institutional environment and GRP. It is these interactions that determine the type of regional institutional environment. Thus, through this approach, we can gain a better understanding of whether the institutional environment actually fulfills its functions and enables innovation or not. The results of this analysis can be used to identify the areas for improvement and the corresponding measures.

The proposed approach, including the algorithm of analysis, is illustrated by the scheme in Figure 1.

For analysis we selected the following Russian regions: Sverdlovsk region, which is of prime importance for our research; Chelyabinsk region; Tyumen and Kurgan regions; the Khanty-Mansi and Yamalo-Nenets autonomous districts; the Republic of Tatarstan; Tomsk and Novosibirsk regions (these regions are among the innovation leaders in Russia); the Republic of Ingushetia; Jewish Autonomous District; and the Chechen Republic (the latter three are lagging in terms of innovation).

The indicators to evaluate the relationships between the government, business and universities were selected by using the parameters specified in official strategic planning documents ${ }^{1}$. Our study also relied on the official open sources of data, including the statistical database of the Federal State Statistics Service, Higher School of Economics, Ministry of Education and Science (until 2018) and other organizations and agencies. Another condition that we had to take into account was the availability of data for the regions we chose for a period of over 5 years. Since absolute indicators to a great extent depend on the size of the regional economy and do not always reflect its growth trends, we converted them into relative indicators. As a result, the following set of indicators was built:

\section{Government performance indicators}

1.1. Volume of shipped innovative goods, works, services per 1 rouble of government funding for universities, rbs

1.2. Volume of shipped innovative goods, works, services per 1 rouble of government funding for the development of innovation infrastructure, rbs

1.3. Volume of shipped innovative goods, works, services per 1 rouble of government funding for $\mathrm{R} \& \mathrm{D}$ and innovation, rbs

1.4. Scholarships paid to university students, rbs per person

2. Indicators of universities' research productivity

2.1. Number of technopark units established at universities per 1 rouble of state funding to universities, units

2.2. Number of technopark units established at universities per 1 student, units

2.3. Volume of shipped innovative goods, works, services per 1 rouble of organizations' own expenditures on $\mathrm{R} \& \mathrm{D}$, rbs

2.4. Volume of shipped innovative goods, works, services per 1 researcher, rbs

${ }^{1}$ Derbeneva A.A. Formation of the Institutional Environment for the Innovation-Oriented Development of Russian Regions: extended abstract of the dissertation for the degree of Cand. Sc. (Economics): 08.00.05. Kazan, 2012. 24 p. (In Russ.); Napolskih D.L. (2014). Institutionalization of Innovative Clusters in the Conditions of the Modern Russian Economy: abstract of the dissertation for the degree of Cand. Sc. (Economics): 08.00.01. Kazan, 26. (In Russ.) 


\section{Indicators of business sector performance}

3.1. Public spending on higher education per student, rbs

3.2. Public spending on academic R\&D per student, rbs

3.3. Volume of innovative goods, works, services per 1 rouble of public spending on higher education, rbs

3.4. Volume of innovative goods, works, services per 1 rouble of public spending on academic $\mathrm{R} \& \mathrm{D}$, rbs

We used the integral index to group the regions into clusters with similar characteristics. Such clusters can be further used to develop management interventions to improve the institutional environment.
Cluster analysis of the given regions was conducted by applying the Agglomerative Hierarchical Clustering (AHC) method, which works best for a small number of observations, with the help of software package IBM SPSS Statistics 23.

The next stage of the proposed approach is correlation regression analysis, which shows the correlation between the selected indicators and GRP of Russian regions. The results at this stage can be used to identify the areas for management intervention.

The aim of regression analysis is to establish a functional relationship of the type $y=f(x)$ between GRP per capita and the indicators selected through correlation analysis. Thus, we will be able to show the quantitative relationship be-

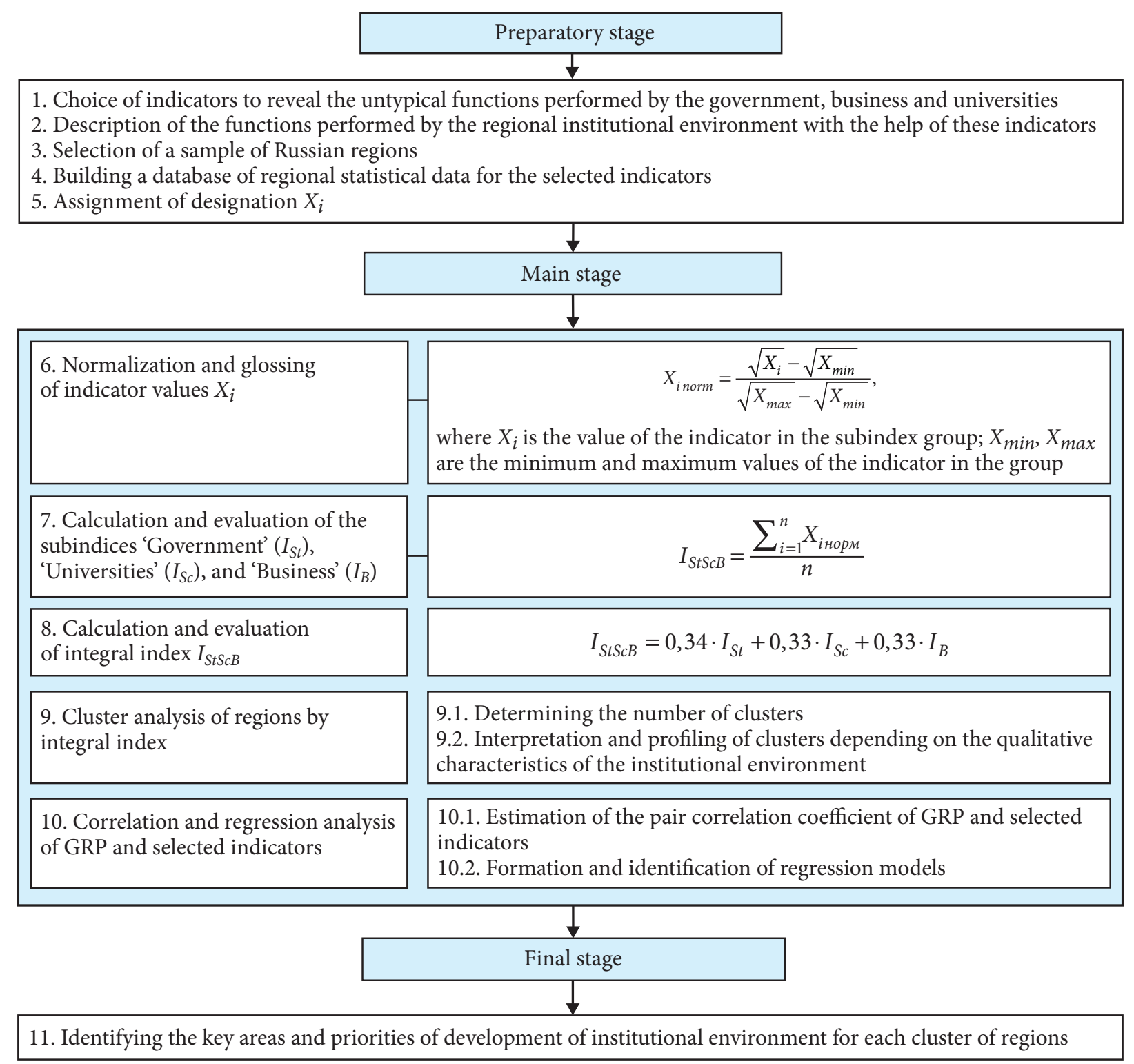

Figure 1. Methodology for the evaluation of the regional institutional environment Source: developed by the authors 
tween the resultant indicator and the factors that influence it. The models were based on the indicators with positive correlation coefficients with values above 0.70 .

\section{Results}

The integral index was calculated for selected regions by using the set of indicators (Table 1). As Table 1 shows, the performance of Tyumen and Chelyabinsk region, the Jewish Autonomous Region, the Khanty-Mansi and Yamalo-Nenets autonomous districts and the Republic of Ingushetia improved over time. In other regions, the rates of growth in the integral index are below $100 \%$.

Table 2 shows clusters of regions based on the data for 2013-2018. Different clusters correspond to different qualitative characteristics of the institutional environment ${ }^{2}$. The clusters were ordered from the highest to the lowest values of the centroid (mean value). This way we could rank regional institutional environments and identify their specific types. Table 2 illustrates the dynamics of integral index $I_{S t S c B}$ of Russian regions.

We conducted a cluster analysis of Russian regions based on the integral index $I_{S t S c B}$ for 2013-2018. The long-standing leader is the Republic of Tatarstan, which was classified into the first cluster. In comparison with other regions, Tatarstan boasts a higher quality institutional

${ }^{2}$ Lyashenko E.A. Development of the Regional Institutional Environment for Technoparks: dissertation for the degree of Cand.Sc. (Economics): 08.00.05/ Elena Lyashenko; [Defended at the Ural State Economic University]. Ekaterinburg, 2020. 333 p. (In Russ.) environment, which is more dynamic, innovation-oriented, stable, and also better developed. In the given period, such regions as Ingushetia and Chechnya belonged to the cluster of laggards. The Jewish Autonomous Region, which also lags behind on innovation, belonged to this cluster between 2013 and 2015. Other regions were either in the second or third clusters, which are quite close in terms of the integral index's values.

The statistical evaluation of the coefficients of the pair correlation between GRP per capita and 12 indicators characterizing the relationships between the government, business and universities has led us to the following conclusion. In general, it would be fair to say that potentially, each indicator has a strong or very strong positive correlation with GRP per capita (the correlation coefficient is over 0.7 and over 0.9 ).

The group of struggling regions (Ingushetia and Chechnya) has the smallest number of indicators closely linked to GRP per capita. For instance, Ingushetia has only one positive correlation coefficient above 0.50 (Indicator 2.4). This means that the institutional environment in these regions is inadequate, that is, there is uncertainty in the behaviour of the stakeholders involved in interactions, their behaviour is uncoordinated, the structure of their interactions is not quite stable, and they lack incentives to collaborate with other stakeholders.

For Tatarstan, Tyumen and Sverdlovsk regions we found a strong and very strong positive correlation between over a half of the indicators and GRP per capita. These regions boast a higher

Integral index $I_{S t S c B}$ of Russian regions for 2013-2018

Table 1

\begin{tabular}{|l|c|c|r|r|r|r|r|}
\hline \multicolumn{1}{|c|}{ Regions } & $\mathbf{2 0 1 3}$ & $\mathbf{2 0 1 4}$ & $\mathbf{2 0 1 5}$ & $\mathbf{2 0 1 6}$ & $\mathbf{2 0 1 7}$ & $\mathbf{2 0 1 8}$ & $\begin{array}{c}\text { Growth rate } \\
\mathbf{2 0 1 8} / \mathbf{2 0 1 3} \mathbf{\%}\end{array}$ \\
\hline Kurgan region & 0.5324 & 0.5222 & 0.4594 & 0.4215 & 0.4620 & 0.4024 & 75.58 \\
\hline Sverdlovsk region & 0.4831 & 0.4996 & 0.4698 & 0.5365 & 0.5249 & 0.4367 & 90.39 \\
\hline Tyumen region & 0.3395 & 0.3990 & 0.4142 & 0.6501 & 0.6648 & 0.6530 & 192.31 \\
\hline Chelyabinsk region & 0.4435 & 0.4787 & 0.4685 & 0.5133 & 0.6018 & 0.5187 & 116.95 \\
\hline Khanty-Mansi Autonomous District & 0.3085 & 0.3558 & 0.3860 & 0.4153 & 0.4023 & 0.4253 & 137.84 \\
\hline Yamalo-Nenets Autonomous District & 0.2295 & 0.2848 & 0.4210 & 0.3556 & 0.2469 & 0.2314 & 100.79 \\
\hline Tatarstan & 0.7361 & 0.7328 & 0.6893 & 0.6627 & 0.6428 & 0.6075 & 82.52 \\
\hline Tomsk region & 0.4507 & 0.4137 & 0.4114 & 0.4193 & 0.4203 & 0.4054 & 89.95 \\
\hline Novosibirsk region & 0.3735 & 0.3967 & 0.3762 & 0.4144 & 0.4308 & 0.3702 & 99.12 \\
\hline Ingushetia & 0.1743 & 0.1819 & 0.2222 & 0.2100 & 0.2176 & 0.2032 & 116.61 \\
\hline Jewish Autonomous Region & 0.1746 & 0.2585 & 0.2635 & 0.3426 & 0.4840 & 0.3814 & 218.42 \\
\hline Chechnya & 0.1716 & 0.1685 & 0.2440 & 0.1939 & 0.2620 & 0.1498 & 87.27 \\
\hline
\end{tabular}

Source: compiled by the authors 
Table 2

Clusters of regions by integral index $I_{S t S C B}$ in 2013-2018



Source: compiled by the authors 
level of institutional development: the degree of uncertainty is lower and the interests of the key actors are better coordinated, partnerships are encouraged, the system of training and knowledge transfer is well developed, the structure of interactions is quite stable.

Sverdlovsk region ranks high in the correlation coefficients among other regions. We found a strong and very strong positive correlation between the growth of GRP per capita and indicators $1.1,1.4,2.2,2.3,2.4,3.1,3.2$. In other words, an increase in the following indicators affects the growth of GRP per capita:

- volume of shipped innovative goods, works, services per 1 rouble of government funding for universities, rub (1.1);

- scholarships paid to university students, rbs per person (1.4);

- number of technopark units established at universities per 1 student (2.2);

- volume of shipped innovative goods, works, services per 1 rouble of organizations' own expenditures on $\mathrm{R} \& \mathrm{D}$ (2.3);

- volume of shipped innovative goods, works, services per 1 researcher (2.4)

- public spending on higher education per student (3.1);

- public spending on academic R\&D per student (3.2).

As our correlation analysis shows, in Sverdlovsk region the following indicators need improvement:

- volume of shipped innovative goods, works and services per 1 rouble of spending on the development of innovation infrastructure (1.2)

- volume of shipped innovative goods, works and services per 1 rouble of spending on $R \& D$ and innovation (1.3);

- number of technopark units established at universities per 1 rouble of state funding to universities (2.1);

- volume of innovative goods, works and services per 1 rouble of funding for education (3.3).

- volume of innovative goods, works and services per 1 rouble of funding for research (3.4).

Thus, the correlation analysis has revealed the strength and direction of the relationship between GRP per capita and the indicators. The correlation coefficients are significant, which means that there is a significant relationship between the data. It, therefore, makes sense to conduct regression analysis and build a model to explain the relationship between the data and to make predictions.
We need to establish the functional relationship of the type $\mathrm{y}=\mathrm{f}(\mathrm{x})$ between GRP per capita and the indicators selected through correlation analysis. Thus, we will be able to show the quantitative relationship between the resultant indicator and the factors that influence it. The models were based on the indicators with positive correlation coefficients above 0.70 .

Identification of the regression models has shown that there is a linear as well as non-linear relationship between the indicators. This relationship is observed in the majority of cases and is characterized by polynomial models of the type $y=a+b_{1} \cdot x+b_{2} \cdot x^{2}+b_{3} \cdot x^{3}$. The relationship varies across regions and indicators (for more on this, see: E.A. Lyashenko ${ }^{3}$ ).

As our regression analysis has shown, in almost every cluster, except for the clusters based on indicators 2.1 and 2.3, there are models characterizing the influence of the indicators on GRP per capita. Most models demonstrate a positive relationship, which means that the more effective are the interactions between the government, business and universities, the larger is GRP and GRP per capita.

There are no models for the struggling regions (Ingushetia and Chechnya), which means that the relationships between the government, business and universities are ineffective, in other words, their regional institutional environment is inadequate. In other regions, the indicators that had the most significant positive impact on GRP per capita were the amount of funding for education and research; scholarships paid to university students; and the number of technopark units established at universities. In some regions (Tatarstan, Tomsk and Novosibirsk), the number of technopark units established at universities has a considerable impact on GRP. An increase in the volume of shipped innovative goods, works, services per 1 rouble of spending on $\mathrm{R} \& \mathrm{D}$ also leads to an increase in GRP, but to a lesser extent (Kurgan, Tomsk and Novosibirsk regions). In the majority of regions, an increase in the amount of state scholarships paid to students leads to a fall in GRP.

Evaluation of the regression models for Sverdlovsk region in comparison with other regions has led us to identify the following areas for growth and improvement:

${ }^{3}$ Lyashenko E.A. Development of the Regional Institutional Environment for Technoparks: dissertation for the degree of Cand.Sc. (Economics): 08.00.05/ Elena Lyashenko; [Defended at the Ural State Economic University]. Ekaterinburg, 2020. 333 p. (In Russ.) 
- volume of shipped innovative goods, works, and services in relation to spending on the development of innovation infrastructure (an example to aspire to in this regard may be the well-developed innovation infrastructure in Novosibirsk region);

- volume of shipped innovative goods, works, services per 1 researcher, rbs (a reference region in this regard may be Tomsk region);

- commercial funding for higher education per student (a reference region may be Novosibirsk region);

- commercial funding for academic research per student (a reference region may be the Yamalo-Nenets Autonomous District);

- the volume of innovative goods, works and services per 1 rouble of business funding for education (a reference region may be Tyumen region);

- the number of technopark units established at universities per 1 student (reference regions may be Tatarstan and Novosibirsk regions).

\section{Discussion and implications}

Our analysis has shown the possible areas of improvement for the selected Russian regions. For each group of regions, a specific set of policies and measures should be devised: for instance, regions of the first cluster need smaller adjustments to enhance their institutional environments; regions of the second cluster, moderate adjustments; regions of the third cluster, more substantial adjustments (active interventions); and regions of the fourth cluster, considerable adjustments (radical interventions). The significance of the government's role increases from group 1 to group 4. Mechanisms recommended for the first and second groups of regions are aimed primarily at mitigating and/ or neutralizing negative factors; for the third and fourth groups, the mechanisms should be aimed at eliminating the impediments to the development of an adequate institutional environment.

For regions of the first cluster (Tatarstan, Tyumen region) and of the second cluster (Chelyabinsk region), the following measures are proposed:

a) it is necessary to create a centre to coordinate interactions between the government, business and universities;

b) individuals and legal entities should be subject to administrative/ criminal liability for the misappropriation or misuse of public funds, abuse of tax breaks, and so on;

c) concerted efforts are needed to attract investment to the territory with the help of tax incentives; d) for individuals and legal entities engaged in innovation activities, lower income and property tax rates may be provided;

e) preferential tax treatment should be offered to businesses engaged in cooperation projects with universities and research institutions;

f) preferential tax treatment should be offered to the universities engaged in cooperation projects with businesses.

These measures may be described as adjustment interventions or moderate interventions. Although they appear almost identical, in the latter case the measures are likely to produce stronger effects (e.g. lower tax rates are applied).

For regions of the third cluster (Sverdlovsk and Kurgan regions, the Khanty-Mansi Autonomous District, Tomsk and Novosibirsk regions, the Jewish Autonomous Region) and of the fourth cluster, the following measures are proposed:

a) it is necessary to create a centre to coordinate interactions between the government, business and universities;

b) more funding should be allocated to the sphere of science and education in these regions;

c) venture capital financing should be used;

d) individuals and legal entities should be subject to administrative/ criminal liability for the misappropriation or misuse of public funds, abuse of tax breaks, and so on;

r) concerted efforts are needed to attract investment to the territory with the help of tax incentives;

f) for individuals and legal entities engaged in innovation activities, lower income and property tax rates may be provided;

g) preferential tax treatment should be offered to businesses engaged in cooperation projects with universities and research institutions;

h) preferential tax treatment should be offered to the universities engaged in cooperation projects with businesses;

i) preferences and benefits (tax preferences, amortization benefits, preferential pricing, etc.) should be provided;

j) clusters and technoparks should be established and developed;

k) marketing tools should be used to promote innovation.

The above-described measures can be described as active or radical intervention. Active intervention implies a broader range of exemptions and preferences, a more active played by the government in spurring innovation and in creat- 
ing an innovation infrastructure. Radical intervention implies a significant transformation in the regional institutional environment to foster innovation, including the creation of technoparks.

What distinguishes the priorities set for regions of the third and fourth clusters from those of the first and second clusters is that the actors involved in innovation activities, including participants of technoparks, should be freed from bearing the accompanying costs. At the same time, individuals and legal entities should be subject to administrative and criminal liability for the misappropriation or misuse of public funds, abuse of tax breaks, and so on. For regions of the first and second clusters we would recommend milder interventions over more stringent approaches. Undoubtedly, with a few adjustments, the instruments proposed for the regions of the third and fourth clusters can be also applied to other clusters.

As for Sverdlovsk region as the key region of our analysis, it is necessary, first, to stimulate the development of the innovation infrastructure and R\&D by increasing the volume of shipped innovative goods, works and services per 1 rouble of public spending. Second, it is necessary to increase the number of technopark units established at universities and stimulate commercial investment in university research and education.

Overall, Sverdlosvk region ranks high among the other regions in our sample. Regional authorities go to great lengths to create a more favourable environment that would facilitate university-business interactions. Nevertheless, the region still has a long way to go in this respect compared to other, more advanced Russian territories. Companies and universities should be encouraged to forge long-term collaborations. Moreover, it is necessary to increase the amount of government spending on R\&D and innovation and stimulate universities to operate more entrepreneurially, commercializing the results of their $\mathrm{R} \& \mathrm{D}$, and creating knowledge-based enterprises. Taken together, these measures will ensure the development of the regional institutional environment.

\section{References}

Balatsky, E.V., \& Ekimova, N.A. (2016). Assessment of Russia's institutional development. Moscow: Pero, 154. (In Russ.)

Bramwell, A., Hepburn, N., \& Wolfe, D.A. (2012). Growing Innovation Ecosystems: University-Industry Knowledge Transfer and Regional Economic Development in Canada. Final Report to the Social Sciences and Humanities Research Council of Canada.

Caniels, M.C.J., \& van den Bosch, H. (2011). The role of Higher Education Institutions in building regional innovation systems. Papers in Regional Science, 90(2), 271-U377. doi: 10.1111/j.14355957.2010.00344.x

Capello, R. (1999). Spatial transfers of knowledge in high technology milieux: learning versus collective learning processes. Regional Studies, 33(4), 353-366. doi: 10.1080/00343409950081211

Dawley, S., MacKinnon, D., \& Pollock, R. (2019). Creating strategic couplings in global production networks: regional institutions and lead firm investment in the Humber region, UK. Journal of Economic Geography, 19(4), 853-872. doi: 10.1093/jeg/lbz004

Doroshenko, S.V. \& Popov, E.V. (2002). On evolutionary regionomics. Ekonomicheskaya nauka sovremennoj Rossii = Economic Science of modern Russia. 1, 28-37. (In Russ.)

Fonseca, L., \& Nieth, L. (2021). The role of universities in regional development strategies: A comparison across actors and policy stages. European Urban and Regional Studies, 28(3), 298-315. doi: $\underline{10.1177 / 0969776421999743}$

Harmaakorpi, V., \& Rinkinen, S. (2020). Regional development platforms as incubators of business ecosystems. Case study: The Lahti urban region, Finland. Growth and Change, 51(2), 626-645. doi: 10.1111 /grow. 12375

Hasche, N., Höglund, L., \& Linton, G. (2020). Quadruple helix as a network of relationships: creating value within a Swedish regional innovation system, Journal of Small Business \& Entrepreneurship, 32(6), 523-544. doi: 10.1080/08276331.2019.1643134

Leydesdorff, L. (2008). Configurational Information as Potentially Negative Entropy: The Triple Helix Model, Entropy, 10(4), 391-410.

Markov, L.S., Yagolnitzer, M.A., Markova V.M., \& Teplova, I.G. (2009). Institutional features, a clustering model and the innovative development of mesoeconomic systems. Region: ekonomika $i$ sociologiya = Region: Economics and Sociology, 3, 3-18. (In Russ.) 
Mercan, B., \& Göktaş, D. (2011). Components of Innovation Ecosystems: A Cross-Country Study. International Research Journal of Finance and Economics, 76, 102-112.

Kleiner, G.B. (2001). Mesoeconomics of the transition period: markets, industries, enterprises. Moscow: Nauka, 516. (In Russ.)

Nort, D. (1997). Institutions, institutional changes and the functioning of the economy. Moscow: Foundation of the economic Book "Beginnings", 180. (In Russ.)

Nureev, R.M. (2006). Post-Soviet Institutionalism-2006: Power and Business. Rostov-on-Don: Nauka Press. (In Russ.)

Nureev, R.M. (2009). Regionalism: the reserves of the institutional approach. Terra Economicus, 2, 18-41. (In Russ.)

Ott, H., \& Rondé, P. (2019). Inside the regional innovation system black box: Evidence from French data. Papers in Regional Science, 98(5), 1993-2026. doi: 10.1111/pirs.12446

Prokin, V.V. (2016) Theoretical and empirical analysis of the institutional environment of the innovative economy of the region. Teoreticheskiy i empiricheskiy analiz institutsionalnoy sredy innovatsionnoy ekonomiki regiona = Innovative economic development: trends and prospects, 1, 170-183. (In Russ.)

Rodríguez-Pose, A. (2013). Do Institutions Matter for Regional Development? Regional Studies, 47(7), 1034-1047. doi: $10.1080 / 00343404.2012 .748978$

Smorodinskaya, N.V. (2011). The Triple Helix as a new matrix of economic systems. Innovation, 4, 66-78. (In Russ.)

Smorodinskaya, N.V. (2015). The globalized economy: from hierarchies to the network structure. Moscow: Institute of Economics of the Russian Academy of Sciences, 53. (In Russ.)

Weissman, E.D., Podshivalova, M.V. (2017). Methodological foundations of the analysis of the institutional environment of small industrial enterprises. Vestnik Tomskogo gosudarstvennogo universiteta. Ekonomika = Bulletin of Tomsk State University. Economy, 39, 5-23 (In Russ.).

Yoda, N., \& Kuwashima, K. (2020). Triple helix of university-industry-government relations in Japan: Transitions of collaborations and interactions. Journal of the Knowledge Economy, 11(3), 1120-1144. doi: $10.1007 / s 13132-019-00595-3$

Zhuang, T., Zhao, S., Zheng, M., \& Chu, J. (2021). Triple helix relationship research on China's regional university-industry-government collaborative innovation: Based on provincial patent data. Growth and Change, 52(3), 1361-1386. doi: 10.1111/grow.12490

\section{Information about the authors}

Natalia Y. Vlasova - Professor of State and Municipal Governance Department, the Ural State University of Economics (620144, Russia, Sverdlovsk Region, Yekaterinburg, 8 Marta str./Narodnaya Volya,62/45); e-mail: vnj@usue.ru

Elena A. Lyashenko - Associate Professor of State and Municipal Governance Department, the Ural State University of Economics (620144, Russia, Sverdlovsk Region, Yekaterinburg, 8 Marta str./ Narodnaya Volya, 62/45); e-mail: lyashea@usue.ru

ARTICLE INFO: received September 13, 2021; accepted November 4, 2021

\section{Информация об авторах}

Власова Наталья Юрьевна - доктор экономических наук, профессор, профессор кафедры государственного и муниципального управления, Уральский государственный экономический университет (620144, Россия, Свердловская область, г. Екатеринбург, ул. 8 Марта/Народной Воли, д. 62/45); e-mail: vnj@usue.ru

Ляшенко Елена Александровна - кандидат экономических наук, доцент кафедры государственного и муниципального управления, Уральский государственныйэкономический университет (620144, Россия, Свердловская область, г. Екатеринбург, ул. 8 Марта/Народной Воли, д. 62/45); e-mail: lyashea@usue.ru

ИНФОРМАЦИЯ О СТАТЬЕ: дата поступления 13 сентября 2021 2.; дата принятия к печати 4 ноября 2021 г. 